\title{
Wetenskaplike woordidentifikasie en -klassifikasie in Bantoetale met besondere verwysing na Zoeloe
}

\author{
Lionel Posthumus \\ Departement Afrikatale \\ Randse Afrikaanse Universiteit \\ AUCKLANDPARK \\ E-pos: Icpo@Iw.rau.ac.za
}

\begin{abstract}
Scientific word identification and classification in Bantu languages with special reference to Zulu
\end{abstract}

Despite the fact that Van Wyk's word theory (1958) is the only scientifically justified word theory for Bantu languages, his work has not had the expected impact on the study of Bantu languages (especially the Nguni languages). This is partly due to the fact that his thesis was written in Afrikaans and is inaccessible to many Bantu language scholars. Secondly, this state of affairs is due to the fact that his treatise is highly theoretical and that the principles have not been applied exhaustively to Zulu or any of the other Nguni languages. Lombard et al.'s Northern Sotho grammar of 1985 is the only grammar written totally within the Van Wykian framework. The recognition of a word category "particle (word)" is probably the aspect that has had the most far-reaching consequences for a morphological and syntactical analysis of Bantu languages. The justification for distinguishing a word category "particle word" is examined in this article.

\section{Probleemstelling}

Daar is geen eenstemmigheid oor ' $n$ woordteorie wat as vertrekpunt moet dien in die bestudering van Bantoetale nie. Die onderskeie woordteorieë wat as vertrekpunt dien vir Bantoetaalbeskrywing (behalwe dié van Van Wyk, 1958) lei tot ernstige teenstrydighede. Dit is dus nodig om die woordteorieë wat op Bantoetaalstudie toegepas is krities te ondersoek met klem op Van Wyk se werk. Van Wyk het egter in sy publikasies meer op die beginsels van die woordteorie gekonsentreer, terwyl die toepassing van die beginsels op die taal self (veral in die geval van die Ngunitale) nooit in besonderhede bespreek of gedoen is nie. Die 
feit dat Van Wyk se werk in Afrikaans gepubliseer is, en dus ontoeganklik is vir 'n groot aantal Bantoetaalkundiges, het verder daartoe bygedra dat sy teorie nie werklik inslag gevind het in Bantoetaalstudie nie. 'n Vergelyking van Van Wyk se woordteorie met ander prominente Bantoewoordteorieë en die identifisering en beskrywing van die partikelwoorde is noodsaaklik om die waarde van hierdie woordteorie te beklemtoon.

\section{Doel}

Die doel van hierdie artikel is om:

- die tekortkominge binne die tradisionele identifisering en klassifikasie van woorde in woordklasse deur grammatici soos onder meer Doke en Ziervogel en hulle volgelinge uit te wys;

- die regverdiging vir die onderskeiding van 'n woordklas "partikel(woord)"1 te bespreek;

- die partikelwoorde van Zoeloe te identifiseer, te benoem en te lys.

\section{Woordverdeling versus woordidentifikasie}

Dit is noodsaaklik om te onderskei tussen woordverdeling en woordidentifikasie. Woordverdeling is die ortografiese konvensie waarvolgens woordgrense aangedui word in geskrewe taal. Woordidentifikasie, daarenteen, is die proses waarvolgens woorde as taalsimbole binne 'n taalkontinuum geïdentifiseer word deur die aanwending van bepaalde woordidentifikasietoetse.

Die aandui van woordgrense is een van die funksies van 'n ortografie (wat op blote konvensie berus). In tale wat van die Romeinse alfabet gebruik maak, word woordgrense algemeen aangedui deur spasies te laat tussen woorde. Van Wyk (1958:172 e.v.) gee voorbeelde van ortografieë waarin woordgrense nie deur spasies tussen woorde gemarkeer word nie, maar wel deur die invoeging van bepaalde simbole tussen woorde. Die aanduiding van woordgrense is 'n ortografiese konvensie wat nie noodwendig op die resultaat van die toepassing van wetenskaplike woordidentifikasiebeginsels berus nie, en gee ook geen uitsluit-

$1 \quad$ Alhoewel die "woord" in "partikelwoord" toutologies is, word dit nogtans gebruik in hierdie artikel om te beklemtoon dat hierdie taalvorme woordstatus het en volwaardige woorde is. Partikelwoorde is wetenskaplik woorde en nie prefikse of "formatiewe" nie.

Die taalsimbole is: woord, woordgroep en sin. Die term "formatief" wat deur Doke gebruik word, is 'n non-entiteit. 
sel oor die wetenskaplike woordstatus van die taalsimbole wat as woorde gemarkeer is nie.

Probleme rondom woordidentifikasie is nie beperk tot die Bantoetale nie. Van Wyk (1958:174 e.v.) wys op die ontoereikendheid van die konvensionele manier van woordverdeling in 'n aantal tale, waaronder Frans, Duits, Engels en Afrikaans. Hy (Van Wyk, 1958:176) wys daarop dat dit vanweë die ontoereikendheid van die konvensionele ortografie is om woordverdeling bevredigend te markeer (in gevalle waar 'n woordgrens binne 'n sillabe val) dat Engelse woorde soos it's en you're en Franse "woorde" soos l'homme en j'ai met 'n afkappingsteken geskryf word. In teenstelling hiermee word soortgelyke Duitse "woorde" egter ortografies as een woord geskryf. Vergelyk byvoorbeeld, im (< in dem) en vom (< von dem).

Dit blyk duidelik uit die voorafgaande bespreking dat die ideaal is dat woordverdeling voorafgegaan moet word deur ' $n$ wetenskaplik verantwoordbare woordidentifikasieproses. Toepaslike woordidentifikasietoetse (wat gebaseer is op die inherente kenmerke van woorde) moet ontwikkel word om die woorde van 'n bepaalde taal te identifiseer.

\section{Woordidentifikasie versus woordklassifikasie}

Slegs nadat woorde geïdentifiseer is, kan sodanige woorde in woordklasse (of woordkategorieë) geklassifiseer word. Die vraag kan tereg gevra word waarom dit nodig is om woorde sistematies te identifiseer en in woordkategorieë in te deel. In hierdie verband merk Lyons (1990:109) op:

What are traditionally, and rather misleadingly, referred to as parts of speech - nouns, verbs, adjectives, prepositions, etc. - play a crucial role in the formulation of the grammatical rules of the language.

Dit is noodsaaklik om die woorde (wat deur die toepassing van bepaalde woordidentifikasietoetse geïdentifiseer is) in woordklasse in te deel. Tensy woorde met eenderse kenmerke saam in woordklasse gegroepeer word, is dit onmoontlik om die ooreenkomste en verskille tussen hulle sistematies te beskryf. Die klassifikasie van woorde in woordklasse is ook ' $n$ voorvereiste vir 'n omvattende en samehangende beskrywing van die onderskeie dissiplines van die taal wat bestudeer word.

\section{Doke (1927) se woordidentifikasie en -klassifikasie}

Doke se woordkategorieë (of "parts of speech", soos hy dit noem) geniet, ondanks ernstige tekortkominge, steeds wye erkenning in die bestudering en beskrywing van Zoeloe (en ander Bantoetale). 


\subsection{Doke se woordidentifikasie}

Aangesien korrekte woordidentifikasie en -klassifikasie 'n absolute voorvereiste is (veral vir 'n sintaktiese beskrywing van 'n taal), is dit nodig om Doke se woordidentifikasie en -klassifikasie krities te ontleed, veral omdat die woordkategorieë wat hy onderskei, steeds wye erkenning geniet. Dit is noodsaaklik om deeglik kennis te neem van Doke se woordidentifikasie en -klassifikasiebeginsels alvorens Van Wyk se bydrae in hierdie verband onder die soeklig kom.

Doke se bydrae tot die bestudering van Zoeloe (en die ander Bantoetale) moet nie geringgeskat word nie. Sy Textbook of Zulu Grammar van 1927 het 'n groot invloed gehad op die bestudering van Zoeloe. Selfs vandag nog vind vele van die beginsels vir Bantoetaalstudie wat hy uitspel asook die woordklasse wat hy onderskei, in 'n mindere of meerdere mate neerslag in al die Zoeloegrammatikas en -teksboeke. Doke was die eerste Bantoeïs wat probeer het om die woordsoorte wat hy onderskei, te regverdig. Daar kan met reg aanvaar word dat Doke Bantoetaalstudie op ' $n$ wetenskaplike grondslag geplaas het. Desnieteenstaande die feit dat hy 'n reuse bydrae gemaak het tot Zoeloetaalstudie is daar egter sekere tekortkominge in sy werk wat in aanmerking geneem moet word, onder meer sy woordidentifikasie en die -klassifikasie. Aangesien korrekte woordidentifikasie en -klassifikasie 'n absolute voorwaarde is vir 'n sinvolle sintaktiese beskrywing van ' $n$ taal, is dit nodig om sy woordteorie onder die vergrootglas te plaas.

Doke $(1981: 27 ; 33)$ verduidelik die beginsels wat sy woordidentifikasie en -klassifikasie ten grondslag lê in sy Textbook of Zulu Grammar. Doke (1981:27) identifiseer woorde in terme van wat hy beskryf as "klem" en definieer die woord dan as "containing one and only one main stress, usually on the penultimate syllable". Hy identifiseer dus woorde in terme van 'n enkele fonologiese kriterium. Die probleem met sy woordidentifikasie is dat hy lengte as klem interpreteer. Dit is nie klem wat op die voorlaaste lettergreep van die woord val nie, maar wel lengte. Maar selfs al sou lengte aanvaar word as die maatstaf waarvolgens woorde geïdentifiseer word, is die probleem steeds dat nie alle Zoeloewoorde oor lengte op die voorlaaste lettergreep beskik nie. Vergelyk in hierdie verband enkellettergrepige woorde soos nje, lo, la, en ideofone soos mimilithi en bhuklu. Doke se metode van woordidentifikasie lei verder ook tot ander inkonsekwenthede. So word die aanwysende voornaamwoord (demonstratief) as 'n afsonderlike woord geskryf in gevalle waar dit in post-posisie tot die antesedentsnaamwoord optree, maar as deel van die antesedentsnaamwoord indien dit in pre-posisie tot sodanige antesedentsnaamwoord optree. Die aanwysende voornaamwoord van 
Zoeloe is dus volgens dié siening, wat sy woordstatus betref, tegelyk as woord en as deel van 'n woord beskou.

Die slotsom waartoe geraak word, is dus dat Doke se woordidentifikasie onbevredigend is, omdat die kriterium wat hy aanwend om woorde te identifiseer op 'n foutiewe aanname berus, naamlik dat Zoeloewoorde gekenmerk word deur klem op die voorlaaste lettergreep en dat sy toets tot bepaalde inkonsekwenthede lei.

\subsection{Doke se woordklassifikasie}

Doke (1981:33) gebruik twee prinsipes om woorde in woordklasse in te deel, te wete funksie en vorm.

Die aanwending van funksie as 'n klassifikasieprinsipe lei Doke onder meer daartoe om sinne te ondersoek waarin verskillende tipes woorde as onderwerp funksioneer. ' $n$ Vergelyking van voorbeeldsinne soos 1, 2 en 3 hieronder lei tot die slotsom dat die gekursiveerde woorde almal dieselfde funksie in die sin vervul en dus tot dieselfde funksieklas hoort.

1. Izinja ziyaluma $=$ Die honde byt.

2. Zona ziyaluma $=$ Hulle byt.

3. Lezi ziyaluma $=$ Hierdies byt.

Doke kom dus tot die slotsom dat al drie hierdie woorde, izinja, zona en lezi, as onderwerp van 'n sin kan optree. Word die funksie van dieselfde drie woorde in voorbeeldsinne soos 4, 5 en 6 hieronder nagegaan, blyk dit dat hulle nou telkens as voorwerp van die sin funksioneer.

4. Abafana babalekela izinja $=$ Die seuns hardloop weg vir die honde.

5. Abafana babalekela zona = Die seuns hardloop weg vir hulle.

6. Abafana babalekela lezi $=$ Die seuns hardloop weg vir hierdies.

Omdat die woorde in kursief in voorbeeldsinne 1, 2, 3 en 4, 5 en 6 hierbo telkens dieselfde funksie vervul, hoort hulle tot dieselfde fundamentele woordkategorie. Hy noem hierdie fundamentele woordkategorie die substantief.

Die aanwending van funksie as 'n klassifikasieprinsipe lei daartoe dat Doke ses woordkategorieë onderskei, te wete substantiewe, predikatiewe, kwalifikatiewe, deskriptiewe, voegwoorde en interjektiewe. Hy noem hierdie woordkategorieë "basic/fundamental parts of speech".

Nadat alle woorde in terme van hul funksie ondersoek is, beskryf hy hulle in terme van vorm. Dit impliseer dat alhoewel verskillende soorte sub- 
stantiewe dieselfde funksie in die sin vervul, hulle nie dieselfde vorm het nie. In praktyk kom dit daarop neer dat die ses basiese woordkategorieë (substantief, predikatief, kwalifikatief, deskriptief, voegwoord en interjektief) geherklassifiseer word in terme van hul vorm. Doke noem die woordkategorieë wat hy sodoende onderskei "real parts of speech".

Die aanwending van vorm as 'n klassifikasieprinsipe kan geïllustreer word deur na voorbeelde 1, 2 en 3 hierbo te verwys. Alhoewel die woorde, izinja, zona en lezi almal as die onderwerp van 'n sin aangewend kan word, het hulle nie dieselfde morfologiese vorm nie. Morfologies bestaan die woord izinja byvoorbeeld uit 'n pre-prefiks $i-$, 'n ware prefiks -zin(i)- en 'n naamwoordwortel -nja en die woord zona uit 'n kongruensiemorfeem zi-, 'n pronominale morfeem -o- en 'n emfatiese voornaamwoordwortel -na. Die woord lezi weer bestaan uit 'n demonstratiewe morfeem la- gevolg deur die norm van die volle klasprefiks (minus die nasaal en vokaal wat daarop volg) dus izin(i)-. Hierdie drie woorde vervul dieselfde funksie in die sin en word daarom geklassifiseer as behorende tot dieselfde fundamentele woordkategorie, naamlik substantief. Word hulle egter morfologies vergelyk, blyk dit dat hulle wel in hierdie opsig onderling verskil en dus verskillende ware woordkategorieë konstitueer, naamlik respektiewelik 'n naamwoord, 'n "absolute" voornaamwoord en 'n demonstratiewe voornaamwoord. In terme van Doke se klassifikasieprinsipes moet 'n naamwoord dus beskryf word as 'n woord wat funksioneel as 'n onderwerp of voorwerp kan optree en wat vormlik beskik oor die basiese morfologiese struktuur: pre-prefiks + ware prefiks + naamwoordworte/2.

Vir die doel van hierdie artikel is dit ook nodig om Doke se basiese woordkategorie "kwalifikatief" krities te evalueer. Doke onderskei 'n woordkategorie "kwalifikatief" omdat hy 'n aantal "woorde" identifiseer wat in terme van hulle funksie 'n "substantief kwalifiseer". 'n Vergelyking van die morfologie van hierdie "woorde" bring aan die lig dat hulle struktureel verskil. Alhoewel die kwalifikatiewe omkhulu (= wat groot is), omanzi (= wat nat/groen is), omunye (= wat een is) en wami (= myne) almal die substantief umuthi (= die/'n boom), kan kwalifiseer, verskil hulle vormlik. Doke onderskei dan vier tipes kwalifikatiewe, naamlik adjektiewe, relatiewe, enumeratiewe en possessiewe.

Alhoewel Doke 'n prysenswaardige poging aangewend het om die probleme met betrekking tot woordidentifikasie en -klassifikasie in

2 Doke gebruik die term "naamwoordstam". Vir 'n bespreking van die regverdiging vir die gebruik van die term "naamwoordwortel" in plaas van "naamwoordstam” kyk Posthumus (1994:30). 
Bantoetale te hanteer, word sy bydrae deur ernstige tekortkominge gekortwiek. Ten spyte van hierdie tekortkominge is sy woordteorie vir dekades nagevolg deur die meerderheid Bantoetaalkundiges en is sy teorie (of 'n aangepaste vorm daarvan) steeds die woordteorie wat in praktyk nagevolg word in Bantoetaalstudie in Suid-Afrika. Sommige tekortkominge en teenstrydighede in Doke se woordklassifikasie wat veral ernstige implikasies inhou vir 'n sintaktiese beskrywing word vervolgens bespreek. (Hierdie bespreking is gebaseer op die werk van Van Wyk, 1968: 97 e.v.)

Eerstens dui Doke nie aan watter tipe funksie of watter tipe vorm in aanmerking geneem moet word om woorde in woordkategorieë te klassifiseer nie. Dit is byvoorbeeld nie duidelik of hy na sintaktiese of semantiese funksie of na albei verwys nie.

Tweedens bied Doke geen regverdiging aan vir die prosedure wat hy aanwend nie, naamlik om voorrang te verleen aan funksie bo vorm as klassifikasiekriterium.

Hoewel Doke $(1981: 33,34)$ sintaktiese kriteria aanwend om woorde in fundamentele woordkategorieë in te deel, is sy definisies van onder andere die substantief, predikatief en interjeksie gebaseer op suiwer semantiese kenmerke.

Doke se linguistiese woorde stem nie altyd ooreen met sy ortografiese woorde nie. So klassifiseer hy byvoorbeeld die aanwysende voornaamwoord as 'n voornaamwoord, maar ortografies skryf hy hierdie woord konjunktief (dus vas aan die antesedentsnaamwoord) as dit in preposisie tot sodanige naamwoord staan, dus, lelihhashi teenoor die postposisionele bepaling ihhashi leli.

Woorde wat ooglopend verwant is, word in totaal onverwante woordkategorieë geklassifiseer. Doke klassifiseer die "woord" omkhulu (= wat groot is) in die woordkategorie adjektief (wat 'n subkategorie van die fundamentele woordklas kwalifikatief is) terwyl hy die woord mkhulu (= is groot) as 'n kopulatief klassifiseer (wat 'n subkategorie van die fundamentele woordklas predikaat is). Die noue verwantskap van woorde soos hierdie moet tog op 'n manier in die woordsoortkategorisering weerspieël word.

Doke klassifiseer lokatiefafgeleide naamwoorde soos edolobheni as bywoorde vanweë hulle gebruik in voorbeeldsinne soos: Baya edolobheni (= Hulle gaan dorp toe). Die probleem is dat edolobheni gekwalifiseer kan word deur 'n "kwalifikatief' in 'n voorbeeldsin soos, Baya edolobheni elikhulu (= Hulle gaan na die groot dorp toe) waar 
elikhulu ooglopend edolobheni kwalifiseer. Laasgenoemde voorbeeld impliseer dat 'n bywoord deur 'n kwalifikatief gekwalifiseer kan word! Nóg Doke se definisie van die bywoord nóg sy definisie van die kwalifikatief maak egter voorsiening hiervoor. Sy definisie van die bywoord het 'n verdere tekortkoming in soverre dit slegs vir woorde voorsiening maak. Bywoordelike of deskriptiewe bepalings kan ook woordgroepe insluit, soos in die voorbeelde: Usebenza kahle kakhulu (= Hy/Sy werk baie hard) en Uhamba ngebhayisikili (< ng(a) (i)bhayisikili) (= Hy/Sy ry met 'n fiets).

Doke klassifiseer 'n naamwoord wat as vokatief gebruik word as 'n interjektief. Die probleem hiermee is dat die "interjektief" deur 'n kwalifikatief gekwalifiseer kan word. Vergelyk 'n voorbeeldsin soos Bafana! (= Seuns!) met Bafana bakithi, yizani lapha! (= Seuns van ons, kom hier!) In laasgenoemde voorbeeld word bafana (die vokatief) deur die "kwalifikatief" ('n possessief) bakithi gekwalifiseer. Voorts word die "vokatief" ook nog as die onderwerp van die sin gebruik. Weer eens ondervang Doke se definisies van sowel die vokatief as die kwalifikatief nie hierdie teenstrydighede nie.

Imperatiewe werkwoorde word ook as interjektief geklassifiseer. Die probleem met hierdie klassifikasie is dieselfde as dié wat in die vooafgaande paragraaf bespreek is. In 'n voorbeeld soos Bhala incwadi! (= Skryf 'n boek!) moet verklaar word hoe 'n interjektief 'n voorwerp kan neem. Doke se definisie van die interjektief maak weer eens nie hiervoor voorsiening nie.

Doke klassifiseer taalvorme soos yintombi (= Dit is 'n meisie) as 'n "kopulatief" wat 'n subkategorie van die werkwoord konstitueer. In 'n voorbeeld soos: Yintombi enhle efike izolo (= Dit is 'n mooi meisie wat gister aangekom het), kwalifiseer die "adjektief"' enhle (wat volgens Doke 'n subkategorie van die kwalifikatief is) die kopulatief (wat 'n subkategorie van die predikatief is). Die anomalie wat hieruit voortspruit, is dat die kwalifikatief in hierdie geval 'n werkwoord kwalifiseer, terwyl Doke se definisie van 'n kwalifikatief lui: "A qualificative is a word which qualifies a substantive", met ander woorde 'n kwalifikatief kwalifiseer 'n naamwoord of voornaamwoord.

Doke klassifiseer ideofone as 'n subkategorie van die fundamentele woordklas deskriptiewe. In 'n sin soos: Du, bantwana! (= Stil, kinders!) beskryf die ideofoon nie enige predikaat nie en kan daarom nie as sodanig geklassifiseer word nie.

Uit die voorafgaande bespreking blyk dit duidelik dat as gevolg van ernstige tekortkominge in Doke se woordidentifikasie en -klassifikasie, 
die gebruik van sy woordkategorieë as vertrekpunt nie kan lei tot 'n sistematiese en samehangende sintaktiese beskrywing van Zoeloe nie. Vir die doeleindes van 'n meer verantwoordbare sintaktiese beskrywing van Zoeloe is dit noodsaaklik om 'n wetenskaplik verantwoordbare metode van woordidentifikasie en -klassifikasie as vertrekpunt te neem. Die enigste linguis wat tot op hede 'n alternatiewe woordteorie aanbied wat aan hierdie vereistes voldoen, is Van Wyk.

\section{Van Wyk se woordidentifikasie}

Die enigste taalkundige wat 'n wetenskaplik verantwoordbare metode van woordidentifikasie en -klassifikasie vir Bantoetale ontwikkel het, is Van Wyk. Sy woordteorie kom in die hieropvolgende bespreking onder die soeklig.

Die feit dat 'n Zoeloesin soos Umfana uphuza amanzi (= Die seun drink water) geskryf word met spasies tussen umfana en uphuza en tussen uphuza en amanzi impliseer dat hierdie sin uit drie ortografiese woorde bestaan.

Die probleem is egter dat wat (ortografies) as 'n woord geskryf word, nie noodwendig linguisties ' $n$ woord is nie. In die voorbeeldsin hierbo, is die woordidentifikasie nie problematies nie. In die geval van 'n sin soos Yizinja ezinkulu ezikhonkotha ebusuku (= Dit is die groot honde wat snags blaf), word die dele yizinja en ezinkulu as ortografiese woorde geskryf. Hierdie twee taalvorme is egter in werklikheid nie woorde nie, maar woordgroepe. Yizinja bestaan uit die linguistiese woorde $y(i)$ en izinja, terwyl ezinkulu uit die linguistiese woorde ezi en (zi)nkulu bestaan. Selfs al kan die woorde $y(i)$ en ezi nie selfstandig optree nie, tas dit nie hulle status as linguistiese woorde aan nie, omdat hulle woordstatus op ander gronde berus. Hierdie (en soortgelyke) woorde is partikelwoorde en word altyd in samehang met 'n komplement gebruik.

\section{Van Wyk se metode van woordidentifikasie}

Om die woorde van ' $n$ taal korrek te identifiseer moet ' $n$ bepaalde woordidentifikasietegniek toegepas word. Hierdie woordidentifikasietegniek (wat op bepaalde woordidentifikasieprinsipes berus) moet op die inherente kenmerke van woorde berus. Van Wyk (1958) wys op die ontoereikendheid van die woordidentifikasie- (en woordklassifikasieprinsipes) wat deur 'n verskeidenheid taalkundiges vir verskillende tale gebruik word.

Van Wyk (1967:236) wys daarop dat in teenstelling met morfeme, woorde isoleerbaar en inherent stabiel is. Terwyl woorde in isolasie kan 
optree, kan morfeme nie. Morfeme het 'n vaste volgorde binne die woord. Indien die volgorde van die morfeme in die woord sisabafundisa (< si-sa-ba-fund-is-a = ons-hulle-steeds-onderrig) gewysig word na (a) ba-sa-si-fund-is-a of (b) sa-si-ba-fund-is-a of (c) *si-fund-is-sa-a-ba-, word die woordbetekenis gewysig soos in voorbeelde (a) en (b), of die woord word betekenisloos, soos in voorbeeld (c) hierbo. In teenstelling met morfeme het die woord binne die sin 'n vryer volgorde. Vergelyk byvoorbeeld: Ubaba uyalima (= $\mathrm{Pa}$, hy ploeg) en Uyalima ubaba (= Hy ploeg, $\mathrm{Pa}$ ).

Om te bepaal of 'n spesifieke deel van 'n spraakkontinuum 'n woord konstitueer al dan nie, moet dit aan die woordidentifikasietoetse onderwerp word. Die woordidentikasietoetse wat deur Van Wyk ontwikkel is, berus op die inherente kenmerke daarvan, naamlik dat (1) woorde inherent stabiel is, (2) sommige woorde 'n sin konstitueer en (3) woorde van posisie in die sin kan verwissel en hul verhouding tot mekaar ook kan wissel. Hierdie woordkenmerke vorm die basis vir die woordidentifikasietoetse.

Die vier woordidentifikasietoetse wat deur Van Wyk ontwikkel is (en wat deels gebaseer is op die werk van Guthrie, 1948) is die isoleerbaarheids-, skeibaarheids-, omstelbaarheids- en vervangbaarheidstoets.

Die toepassing van hierdie vier woordidentifikasietoetse lei tot 'n geldige identifikasie van linguistiese woorde vir Zoeloe (of enige ander taal). Dit is egter belangrik om daarop te let dat 'n taalvorm nie aan al vier hierdie woordkenmerke moet voldoen om as 'n woord te kwalifiseer nie. 'n Taalvorm soos umfana is isoleerbaar, skeibaar, omstelbaar en vervangbaar, terwyl 'n taalvorm soos $n g(a)$ in ngisika ngommese (< ng(a) \# ummese) ${ }^{3}$ nie isoleerbaar is nie, maar dit kan nogtans as ' $n$ woord geïdentifiseer word op grond daarvan dat dit skeibaar is. Die $n g(a)$ kan van ummese geskei word deur die voornaamwoord wo(na): ngisika ngawo(na) ummese (< nga \# wo(na) \# ummese) en kwalifiseer daarom om as woord erken te word.

Van Wyk se woordidentifikasie word hieronder verder toegelig.

\subsection{Isoleerbaarheid as 'n woordidentifikasietoets}

Die kleinste taalsimbool wat in isolasie gebruik kan word, is ' $n$ woord. As 'n taalsimbool isoleerbaar is, impliseer dit volgens Van Wyk (1958:301), Guthrie (1970:8) en Lombard et al. (1985:11) dat sodanige vorm in isolasie kan optree. Vergelyk voorbeelde $7 \mathrm{~b}$ en $8 \mathrm{~b}$ hieronder, waarin die

3 Die simbool \# word in hierdie artikel gebruik om woordgrense aan te dui. 
taalsimbole isiZulu en ngiyasebenza isoleerbaar is. Let daarop dat die taalvorme *isi- en *ngi- in die c-sinne nie isoleerbaar is nie en daarom nie as woorde kwalifiseer nie.

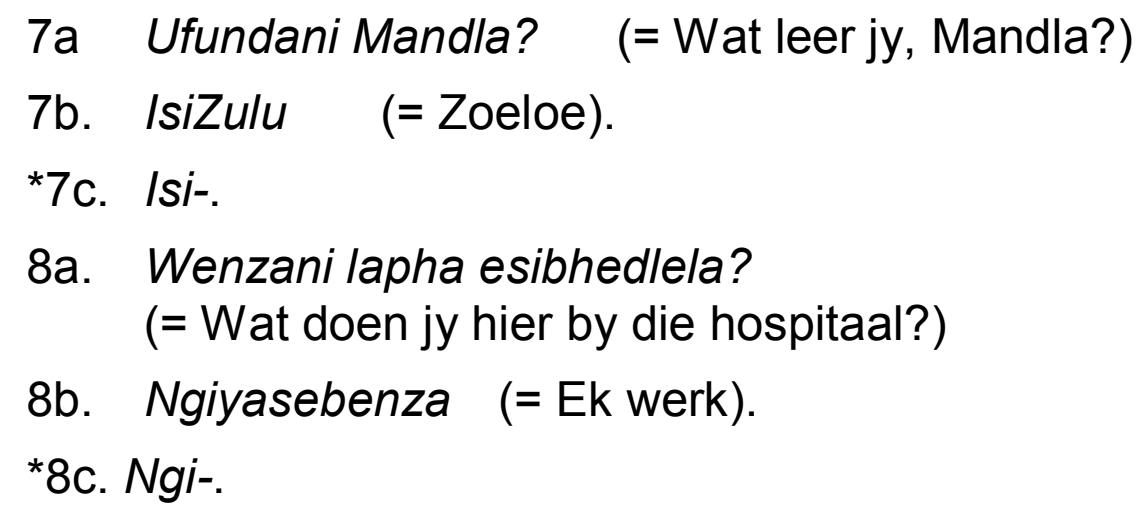

Omdat die taalvorme isiZulu en ngiyasebenza isoleerbaar is, kwalifiseer hulle volgens Van Wyk as woorde.

\subsection{Skeibaarheid as 'n woordidentifikasietoets}

Die kleinste taalvorm wat inherent stabiel is en wat skeibaar is deur ' $n$ woord, is 'n woord. Vergelyk in hierdie verband Van Wyk (1958:310), Guthrie (1970:9) en Lombard et al. (1985:12). Morfeme is ook skeibaar, maar hulle kan slegs deur ander morfeme geskei word en nie deur woorde nie. Die taalvorme ngi- en -dla in die kontinuum ngidla ukudla kan geskei word deur die taalvorm -sa- in die taalkontinuum ngisadla ukudla. Die feit dat ngi- en -dla deur -sa- geskei kan word, beteken egter nie dat die eersgenoemde twee taalvorme woorde is nie (omdat die taalsimbool wat hulle skei, -sa-, nie 'n woord is nie).

Die woordstatus van 'n taalvorm wat vir die skeibaarheidstoets gebruik word, moet (op grond van die isoleerbaarheidstoets) reeds as woord bewys wees. Aangesien die sogenaamde voornaamwoorde reeds as woorde kwalifiseer omdat hulle aan die isoleerbaarheidstoets voldoen, kan hulle aangewend word om die woordstatus van ander woorde te bepaal. Dit is juis die aanwending van die voornaamwoord in die skeibaarheidstoets wat daartoe lei dat die identifiserende kopulatiewe partikel $n g$ (i) as 'n woord geïdentifiseer word. Vergelyk voorbeelde 9a en $9 \mathrm{~b}$ hieronder waar die skeibaarheidstoets bewys dat die identifiserende kopulatiewe partikel $n g(i)$ 'n woord is.

9a. Ngumalume okhulumayo (<ng(i) \# umalume) (= Dit is oom wat praat).

9b. Nguye umalume okhulumayo (<ng(i) \# ye(na) \# umalume) (= Dis die einste oom wat praat). 
Aangesien $n g(i)$ skeibaar is van umalume deur die invoeging van die voornaamwoord ye(na), soos blyk uit voorbeeldsin $9 \mathrm{~b}$ hierbo (en umalume wel 'n woord is op grond van sy isoleerbaarheidskenmerke), kwalifiseer $n g(i)$ ook as 'n woord.

\subsection{Omstelbaarheid as 'n woordidentifikasietoets}

Van Wyk (1958:228 e.v.), Guthrie (1970:11) en Lombard et al. (1985:13 e.v.) wys daarop dat woorde die kleinste taalsimbole is (wat inherent stabiel is) wat omstelbaar is. Vergelyk voorbeeldsinne $10 \mathrm{a}$ en $10 \mathrm{~b}$ hieronder:

10a. Inja iyaluma.

\section{0b. Iyaluma inja (= Dit byt, die hond).}

Omdat inja en iyaluma omstelbaar (en inherent stabiel) is, is hulle albei woorde. Hierdie woordidentifikasietoets bewys ook dat die aanwysende bepaler/voornaamwoord ' $n$ outonome woord is, soos blyk uit ' $n$ vergelyking tussen voorbeeldsinne $11 \mathrm{a}$ en $11 \mathrm{~b}$.

11a. La madoda ayalwa.

11b. Amadoda la ayalwa (= Die manne, hierdies baklei).

Omdat la en amadoda omstelbaar is, kwalifiseer hulle albei as woorde.

\subsection{Vervangbaarheid as 'n woordidentifikasietoets}

Die kleinste taaleenheid (wat inherent stabiel is) wat vervangbaar is deur 'n outonome woord, is ' $n$ woord. Vergelyk in hierdie verband Van Wyk (1958:231 e.v.), Guthrie (1970:10) en Lombard et al. (1985:14). Die toepassing van hierdie toets lei onder meer daartoe dat 'n possessiewe voornaamwoord soos khe as 'n woord geïdentifiseer word. Aangesien die possessiewe voornaamwoord khe vervangbaar is deur die naamwoord umfazi, is khe ook 'n outonome woord. Vergelyk voorbeelde $12 \mathrm{a}$ en $12 b$ hieronder. 
12a. Abantwana bakhe (< ba \# khe) ...

(= Die kinders van haar ...)

12b. Abantwana bomfazi (< ba \# umfazi) ...

(= Die kinders van die vrou ...)

Die sogenaamde possessiefskakel ba kwalifiseer dan ook as 'n linguistiese woord. Die sogenaamde "possessiefskakels" is in der waarheid possessiewe partikelwoorde. Partikelwoorde is woorde wat (soos reeds genoem) wetenskaplik woorde is, maar wat nie isoleerbaar is nie.

Die woordstatus van ba en umfazi kan ook vasgestel word deur die toepassing van die skeibaarheidstoets soos geïllustreer in voorbeelde $12 c$ en $12 d$ hieronder.

12c. Abantwana bomfazi (< b(a) \# (u)mfazi) ...

(= Die kinders van die vrou ...)

12d. Abantwana bakhe umfazi ... (< ba \# khe \# umfazi) (= Die kinders van haar, die vrou ...)

Die skeibaarheidstoets bepaal dat aangesien ba en (u)mfazi skeibaar is deur die invoeging van die possessiewe voornaamwoord khe, ba (die sogenaamde "possessiefskakel") ook wetenskaplik 'n woord is.

\section{Van Wyk se woordklassifikasie}

Van Wyk klassifiseer woorde in woordkategorieë in terme van hul gemeenskaplike sintaktiese, morfologiese, semantiese en fonologiese kenmerke. Hy wend dus al vier vlakke van taalbeskrywing aan om woorde in woordklasse te klassifiseer. In sy voorgestelde klassifikasieprosedure geniet die morfologiese en sintaktiese kriteria voorrang bo die semantiese en fonologiese kriteria.

Van Wyk wys daarop dat terwyl die eerste twee kriteria op sowel vormlike as funksionele kenmerke berus, die laaste twee kriteria (naamlik die semantiese en fonologiese kriteria) nie op sowel vormlike as semantiese kenmerke berus nie. Dit is om hierdie rede dat die morfologiese en sintaktiese kriteria voorrang bo die semantiese en fonologiese kriteria moet geniet. Daar is egter geen regverdiging daarvoor dat die morfologiese kriterium voorrang bo die sintaktiese kriterium moet geniet of vice versa nie. So ook kan die semantiese kriterium nie voorrang bo die fonologiese kriterium geniet (of vice versa) nie.

Die aanwending van hierdie woordklassifikasieprinsipes noodsaak die implimentering van 'n woordklassifikasietegniek. 


\subsection{Van Wyk se voorgestelde woordklassifikasietegniek}

Die aanwending van die vier woordklassifikasieprinsipes wat hierbo vermeld is, noodsaak 'n bepaalde woordklassifikasietegniek wat vyf prosedures veronderstel. Hierdie vyf prosedures word deur van Wyk (1967:251-254) in detail bespreek.

Die eerste prosedure behels 'n omvattende sintaktiese en morfologiese klassifikasie (deur die aanwending van alle moontlike sintaktiese kriteria en morfologiese kriteria op alle geïdentifiseerde woorde), ongeag die aantal potensiële woordklasse wat die aanwending van hierdie prosedure tot gevolg mag hê.

Die tweede prosedure behels dat die resultaat van die eerste prosedure geherevalueer word met die oog daarop om morfologiese klasse vas te stel wat met die sintaktiese klasse korreleer en vice versa. Hierdie prosedure sluit twee stappe in, naamlik om eksklusiewe en inklusiewe ooreenkomste vas te stel. (Die toepassing van hierdie prosedure lei tot die onderskeiding van die volgende woordklasse: naamwoorde, voornaamwoorde [of dan bepalers] werkwoorde en kopulatiewe demonstratiewe.)

Die ongeklassifiseerde woorde (wat morfologies heterogeen is) word dan aan 'n derde woordklassifikasieprosedure onderwerp wat die sintaktiese herklassifisering van die oorblywende woorde behels, waarna die negatiewe morfologiese kenmerke vir elke voorlopige woordklas bepaal word. Hierdie prosedure lei daartoe dat 'n verdere vier woordklasse onderskei word, te wete bywoorde, ideofone, interjektiewe en partikelwoorde.

As daar na die toepassing van hierdie prosedure nog steeds oorblywende ongeklassifiseerde woorde is, word hulle aan 'n vierde prosedure onderwerp wat behels dat sulke woorde geherklassifiseer word, hetsy morfologies of sintakties (watter een van hierdie klassifikasies ook al die kleinste aantal potensiële woordklasse oplewer). Hierdie klasse word dan semanties geanaliseer met die oog daarop om semantiese kenmerke vas te stel wat korreleer met die sintaktiese (of morfologiese) kenmerke. Die toepassing van die vier voorafgaande prosedures lei tot die klassifikasie van al die woorde van 'n bepaalde taal.

Die woordkategorieë wat onderskei is deur die toepassing van die eerste vier prosedures word in die vyfde prosedure geanaliseer om semantiese kenmerke te bepaal wat ooreenstem met die noodsaaklike morfologiese en sintaktiese kenmerke. Die geïdentifiseerde woordkategorieë word dan weer eens geanaliseer om die addisionele fonologiese kenmerke wat 
met die essensiële sintaktiese en morfologiese kenmerke ooreenstem, vas te stel.

In teenstelling met Doke wat die woordklasse definieer in terme van slegs een vlak van taalbeskrywing, definieer Van Wyk die individuele woordkategorieë in terme van die essensiële morfologiese en sintaktiese kenmerke en die addisionele semantiese en fonologiese kenmerke.

\section{9. 'n Vergelyking van Van Wyk se woordkategorieë met dié van ander grammatici}

Die woordkategorieë wat deur grammatici soos Cole (1982), Ziervogel et al. (1978) en Cope (1984) onderskei word, verskil nie noemenswaardig van dié wat Doke onderskei nie. Van Wyk se woordklassifikasie is die enigste wat nie lei tot teenstrydighede nie en wat 'n wetenskaplikgefundeerde basis bied vir die beskrywing van Zoeloe.

Die toepassing van Van Wyk se woordklassifikasieprosedures wat hierbo bespreek is, lei tot die klassifisering van Zoeloewoorde in agt woordsoorte, naamlik: naamwoord, voornaamwoord (of bepaler), werkwoord, bywoord, interjektief, ideofoon, interjektiewe demonstratief en partikelwoord.

Die enigste aanpassing wat aan Van Wyk se woordkategorieë aangebring word, is die erkenning van 'n woordkategorie voegwoord as 'n afsonderlike woordkategorie. Hierdie standpunt is in ooreenstemming met Lombard (1993:88 e.v.). Die woordkategorieë wat vir Zoeloe onderskei word, is dus: naamwoorde, voornaamwoorde (of bepalers), werkwoorde, bywoorde, interjektiewe, ideofone, kopulatiewe demonstratiewe, partike/woorde en voegwoorde.

Wanneer die woordkategorieë wat Van Wyk onderskei, vergelyk word met dié van Doke, blyk dit dat Van Wyk se woordklassifikasie nie kopulatiewe, relatiewe, enumeratiewe en possessiewe (as woorde) insluit nie. In Van Wyk se klassifikasie word die ideofoon as 'n afsonderlike woordkategorie beskou en nie as 'n subkategorie van die deskriptief soos in Doke se klassifikasie nie. Van Wyk klassifiseer ook nie die vokatiewe gebruik van die naamwoord en die imperatiewe gebruik van die werkwoord as interjektiewe nie. Van Wyk (1967:255) wys daarop dat hierdie bepaalde gebruik van die naamwoord en werkwoord nie hierdie woorde se woordkategoriestatus ophef nie. Van Wyk se klassifikasie sluit voorts ook twee woordkategorieë in wat nie in Doke se klassifikasie voorkom nie, naamlik die interjektiewe demonstratief en die partikelwoorde. 


\section{Waarom partikelwoorde onderskei?}

Van Wyk (1958) is die eerste grammatikus wat partikelwoorde in Bantoetale onderskei. Partikelwoorde word in die eerste plek onderskei omdat hierdie woorde as woorde kwalifiseer in terme van die woordidentifikasietoetse.

As 'n taalvormkontinuum soos yintombi yami lena (= Dis my meisie hierdie) aan Van Wyk se woordidentifikasietoetse onderwerp word, blyk dit dat $y(i)$ en (i)ntombi skeibaar is deur die invoeging van die emfatiese voornaamwoord $\mathbf{4}$ yo(na) tussenin, dus: yi- yo(na)-intombi yami lena. Al voldoen die vorm yi nie aan die isoleerbaarheidstoets nie, kwalifiseer hierdie taalvorm as woord op grond daarvan dat dit voldoen aan die skeibaarheidstoets. Soos reeds genoem, het 'n woord slegs nodig om aan een woordidentifikasietoets te voldoen om as woord te kwalifiseer. $y$ (i) kan 'n identifiserende kopulatiewe partikelwoord genoem word omdat hierdie woord slegs in identifiserende kopulatiewe woordgroepe voorkom en hierdie tipe woordgroep van alle ander woordgroepe onderskei.

Voorts word partikelwoorde as woorde onderskei, want alleenlik deur hierdie taalvorme as woorde te onderskei, is ' $n$ sistematiese en samehangende sintaktiese beskrywing van woordgroepe wat sodanige partikelwoorde bevat, moontlik.

In die hieropvolgende bespreking word die probleme bespreek wat op sintaktiese vlak ondervind word indien daar nie 'n woordklas "partikelwoord" onderskei word nie. Volgens Doke se woordteorie is yintombi in die taalkontinuum yintombi enhle ... (= Dis 'n mooi meisie ...) 'n kopulatief (wat 'n subkategorie van die fundamentele woordkategorie predikaat is) terwyl enhle 'n adjektief is (wat 'n subkategorie van die fundamentele woordkategorie kwalifikatief is). Hierdie beskrywing impliseer dus dat die kwalifikatief enhle die kopulatief yintombi kwalifiseer, maar hoe kan 'n kwalifikatief 'n predikaat kwalifiseer? Nêrens maak Doke in sy definiëring van die woordsoorte daarvoor voorsiening dat 'n kwalifikatief 'n predikaat kan kwalifiseer nie. Daar skort dus iets met hierdie sintaktiese beskrywing. Die woordgroep yintombi enhle ... bestaan uit die vier woorde $y(i)$ intombi e nhle (soos duidelik blyk as hierdie taalvorm aan Van Wyk se woordidentifikasietoetse onderwerp word). Dit is duidelik uit die toepassing van 'n wetenskaplike beskrywing dat die kwalifikatiewe woordgroep e \# nhle die naamwoord intombi kwalifiseer wat weer op sy beurt sintakties met die identifiserende kopulatiewe partikelwoord $y(i)$ kombi-

4 Die term "emfatiese/kontrastiewe bepaler/voornaamwoord" is 'n meer toepaslike term vir die sogenaamde "absolute voornaamwoord" (vergelyk Wilkes, 1974, 1976, 1987 en Louwrens, 1981, 1985 in hierdie verband). 
neer (wat funksioneer as 'n inleidende lid vir die woordgroep intombi e \# nhle). In terme van hierdie beskrywing kwalifiseer die kwalifikatiewe woordgroep e \# nhle die naamwoord intombi. Hierdie sintaktiese beskrywing is dan ook in ooreenstemming met die definiëring van die kwalifikatief, naamlik dat dit 'n woord (of woordgroep) is wat 'n naamwoord kwalifiseer (Doke se sogenaamde "substantief").

In 'n woordgroep soos ngisika ngommese omkhulu ... "met 'n groot mes ..." kwalifiseer die adjektief omkhulu (in Doke se terme) die bywoord ngommese. Volgens Doke se definisie kwalifiseer 'n adjektief (as 'n subkategorie van die kwalifikatief) 'n substantief. Tensy ngommese geanaliseer word as bestaande uit 'n partikelwoord $n g(a)$ en 'n naamwoord ummese en daar verder aanvaar word dat die kwalifikatiewe woordgroep o mkhulu die naamwoord ummese kwalifiseer, is 'n wetenskaplik verantwoordbare sintaktiese beskrywing van hierdie woordgroep onmoontlik.

'n Taalvorm soos siba in siba bakhulu (= Ons word groot) konstitueer 'n kopulatiewe werkwoord en nie 'n partikelwoord nie, want dit bestaan morfologies uit die tipiese werkwoordstruktuur, naamlik 'n onderwerpsmorfeem, 'n werkwoordwortel en 'n kategoriale uitgangsmorfeem.

Om te verstaan waarom die onderwerpsmorfeem woordstatus verkry in nie-inchoatiewe kopulatiewe woordgroepe, moet hierdie taalvorme met hulle inchoatiewe teenhangers gekontrasteer word. Vergelyk voorbeeld 13 met 14 , en 15 met 16 :

13. Mina ngimkhulu (< ngi m-khulu).

(< onderwerpsmorfeem (ngi-) - kopulatiewe werkwoordstam *-li \# $m$ - khulu)

(= Ek is groot).

14. Mina ngiba mkhulu (< ngiba m-khulu).

(< onderwerpsmorfeem (ngi-) - kopulatiewe werkwoordstam -ba \# $m$ - khulu)

(= Ek word groot).

15. UThemba unguthisha (< u ng(i) uthisha).

(< onderwerpsmorfeem $(u-)$ - kopulatiewe werkwoordstam *-li \# identifiserende kopulatiewe partikelwoord $n g(i)$ \# naamwoord uthisha)

(= Themba is 'n onderwyser). 
16. UThemba uba nguthisha (<uba ng(i) uthisha).

(< onderwerpsmorfeem (u-) - kopulatiewe werkwoordstam uba \# identifiserende kopulatiewe partikelwoord ng(i) \# naamwoord uthisha)

(= Themba word 'n onderwyser).

Wanneer Zoeloe met ander Bantoetale vergelyk word, blyk dit dat Zoeloe diachronies moontlik ook oor 'n nie-inchoatiewe kopulatiewe werkwoordstam beskik het. Die diachroniese vorm van voorbeeld 13 kan byvoorbeeld gepostuleer word as: "Mina ngi-*ti \# $m$-khulu" wat die nieinchoatiewe kopulatiewe werkwoordstam *-li insluit, met die betekenis van "is". Hoewel hierdie werkwoordstam nie meer in hedendaagse Zoeloe optree nie, is die fonologiese invloed van die vokaal [i] aantoonbaar ${ }^{5}$. Aangesien hierdie werkwoordstam elisie ondergaan het, neem die onderwerpsmorfeem nou die plek in en verrig die funksie van die kopulatiewe werkwoord, en kan dit inderdaad in alle gevalle vervang word met die inchoatiewe kopulatiewe werkwoord. Dit is om hierdie rede dat die onderwerpsmorfeem in hierdie gevalle woordstatus verkry en 'n partikelwoord word. 'n Sinchroniese vergelyking van voorbeeldsinne 14 en 16 bring aan die lig dat terwyl voorbeeldsinne 14 en 16 die kopulatiewe werkwoordstam -ba bevat, voorbeeldsinne 13 en 15 geen kopulatiewe werkwoordstam bevat nie. (Hierdie onderskeid word ook in die negatief van hierdie kopulatiewe woordgroepe gehandhaaf.)

Die antwoord op die vraag hoe kopulatiewe, adjektiewe, relatiewe en possessiewe in Van Wyk se benadering geakkommodeer word, lê in die resultaat van sy woordidentifikasietoetse. Hierdie taalvorme is nie woorde nie, maar wel woordgroepe. (Hulle bestaan uit meer as een woord en kan nie geklassifiseer word as behorende tot 'n woordkategorie nie, want woordklassifisering behels die klassifikasie van individuele woorde in woordkategorieë en nie woordgroepe nie.)

Die toepassing van Van Wyk se woordidentifikasietoetse lei daartoe dat 'n kopulatiewe woordgroep soos siba bakhulu beskryf word as bestaande uit die twee woorde siba ('n kopulatiewe werkwoord) en bakhulu ('n adjektiefnaamwoord). Op dieselfde wyse word die kopulatiewe woordgroep simanzi beskryf as bestaande uit die woorde: si (die kopulatiewe partikelwoord) gevolg deur die relatiewe naamwoord manzi.

5 Grammatici wat 'n onderliggende kopulatiewe werkwoordstam *-li in die positiewe vorm van die nie-inchoatiewe kopulatiewe erken, is onder meer: Meinhof (1948), Van Wyk (1953), Van Eeden (1956), De Clercq (1958), Krüger (1969), Lanham (1971), Wilkes (1974), Poulos (1982, 1990) en Posthumus (1978, 1980, 1988). 


\section{Wat is 'n partikelwoord?}

Partikelwoorde is wetenskaplik woorde, selfs al word hulle in die praktiese Zoeloe- (en ander Ngunitale se) ortografie konjunktief (met ander woorde as deel van ander woorde) geskryf. Partikelwoorde is afhanklike woorde wat in gebruik altyd 'n komplement vereis. Hierdie woorde voldoen egter nie aan aan die isoleerbaarheidstoets nie, maar kwalifiseer nogtans as woorde omdat hulle voldoen aan ten minste een van die ander woordidentifikasietoetse wat op woordmobiliteit berus, naamlik die skeibaarheidstoets en die vervangbaarheidstoets. Die volgende partikelwoorde word vir Zoeloe onderskei:

1. Konnektiewe partikelwoord na soos in die voorbeeld uVusi noThembi $\ldots(<\boldsymbol{n}(\mathbf{a}) \#(u)$ Thembi $)=$ Vusi en Thembi ...).

2. Assosiatiewe partikelwoord na soos in sinamanzi ... $(<$ si \# n(a) \# (a)manzi = ons het water).

3. Vergelykingspartikelwoorde njenga en nganga soos in die voorbeelde njengentaba (< njeng(a) \# (i)ntaba = soos 'n berg), ngangendlovu (< ngang(a) \# (i)ndlovu = so groot soos 'n olifant).

4. Instrumentale partikelwoord nga soos in die voorbeeld usika ngommese (< ng(a) \# (u)mmese = met'n mes).

5. Referensiële partikelwoord nga soos in die voorbeeld ngikhuluma ngabo (< nga \# bo(na) = ek praat van hulle).

6. Kopulatiewe partikelwoorde (die sogenaamde "onderwerpskakels" van die nie-inchoatiewe kopulatiewe) soos in die voorbeelde umkhulu ( $<\boldsymbol{u} \#$ \#-khulu = jy is groot); linenxeba (< li \# n(a) \# (i)nxeba = hy (die ouman) het 'n wond; ziyizilwane (< zi \# y(i) \# izilwane = hulle (donkies) is diere).

7. Negatiewe kopulatiewe partikelwoorde soos in die voorbeeld awumkhulu (< awu \# m-khulu = jy is nie groot nie); alinanxeba ( $<$ ali \# na \# (i)nxeba = hy (die ouman) het nie 'n wond nie) en aziyizilwane (< azi \# y(i) \# izilwane = hulle (donkies) is nie diere nie).

8. Lokatiewe partikelwoord ku soos in die voorbeeld kumama (< ku \# (u)mama = by ma).

9. Lokatiewe possessiewe partikelwoord kwa soos in die voorbeeld kwamalume (< kwa \# (u)malume = by die plek van oom).

10. Possessiewe partikelwoorde soos byvoorbeeld za en sika in die voorbeelde izinja zami (< za \# mi(na) = die hond van my) en isithuthuthu sikababa (< sika \# (u)baba = die motorfiets van pa).

11. Kwalifikatiewe partikelwoorde (die sogenaamde "relatiefskakels" in sogenaamde "kopulatiewe konstruksies") soos byvoorbeeld 
elinamandla (< eli \# n(a) \# (a)mandla = hy (die ouman) wat krag het) en abangothisha (< aba \# ng(i) \# (o)thisha = hulle wat onderwysers is).

12. Klitiese partikelwoorde bo en $k e$ in voorbeelde soos Hamba bo = loop dan enYikhomputha-ke lena = dit dan is 'n rekenaar.

13. Hortatiewe partikelwoorde ake, ma en a in voorbeelde soos ake sihambe, masihambe en asihambe = laat ons loop.

14. Interrogatiewe partikelwoorde in voorbeelde soos ufike nini? = wanneer het jy gekom?, uyadla na? = eet jy? en Uhlala kuphi? = waar woon/bly jy?

15. Identifiserende kopulatiewe partikelwoorde $n g(i)^{6}, y(i)$ en $w(u)$ soos in die voorbeelde ngingumfana (< ngi \# ng(i) \# umfana = ek is 'n seun); ngiyindoda (< ngi \# y(i) \# indoda = ek is 'n man) en wumlilo lona $(<w(u) \#$ umlilo = dit is 'n vuur).

16. Agentiewe partikelwoorde $y(i), n g(i)$ en $w(u)$ in voorbeelde soos sibonwe yinkosi $(<y(i) \#$ inkosi $=$ ons is gesien deur die koning/hoofman), sisizwe nguThemba ( $<$ ng(i) \# uThemba = ons is gehelp deur Themba); sibizwe wumfowethu $(<\mathbf{w}(\mathbf{u})$ \# umfowethu $=$ ons is geroep deur my broer).

\section{Slotopmerking}

In hierdie artikel is betoog dat Van Wyk se woordteorie die enigste een is waarin woordidentifikasie en -klassifikasie lei tot 'n sistematiese en samehangende beskrywing van Zoeloe (en ander Bantoetale). Die onderskeiding van 'n woordkategorie "partikelwoord" is die verreikendste resultaat van Van Wyk se woordteorie. Dit is dan juis hierdie aspek van Van Wyk se woordteorie wat in meer besonderhede in hierdie artikel bespreek is.

\section{Bibliografie}

Cole, D.T. 1982. An introduction to Tswana. (4th impression). Johannesburg : Longman Penguin Southern Africa.

Cope, A.T. 1984. An outline of Zulu grammar. African Studies, 43(2):83-102.

De Clercq, J. 1958. Die kopulatief of nie-verbale predikaat in Nguni en Sotho: met besondere verwysing na Zulu en Suid-Sotho. Stellenbosch : Universiteit van Stellenbosch. (MA-verhandeling.)

Doke, C.M. 1981. Textbook of Zulu grammar. (Sixth edition.) Cape Town : Longman Penguin Southern Africa.

$6 \quad$ Vir die regverdiging van die postulering van $n g(i)$ as kopula van die identifiserende kopulatiewe kyk Posthumus 1978:53, 56 e.v.). 
Guthrie, M. 1970. Bantu word division. In: International African Institute Memorandum XXII, 1948. Collected Papers on Bantu Linguistics. Westmead, Farnborough, England: Gregg International Publishers. p. 5-32.

Krüger, C.J.H. 1969. Klassifikasie van kopulatiewe inleidende lede. Taalfasette, 10:815.

Lanham, L.W. 1971. The noun as the deep-structure source for Nguni adjectives and relatives. African Studies, 30(3 \& 4):299-311.

Lombard, D.P. 1993. Conjunctions in Northern Sotho. In: Von Staden, P.M.S. (ed.) Linguistica Festschrift E.B. van Wyk - 'n Huldeblyk. Pretoria : Van Schaik. p. 88-97.

Lombard, D.P., Van Wyk, E.B. \& Mokgokong, P.C. 1985. Introduction to the grammar of Northern Sotho. Pretoria : Van Schaik.

Louwrens, L.J. 1981. 'n Perspektief op Wilkes se delisiehipotese oor pronominalisasie in Bantoe. Studies in Bantoetale, 8(1):36-57.

Louwrens, L.J. 1985. Contrastiveness and the so-called absolute pronoun in Northern Sotho. South African Journal of African Languages, 5(2):58-67.

Lyons, J 1990. Languages and Linguistics. Cambridge : Cambridge University Press.

Meinhof, C. 1948. Grundzüge einer vergleichenden grammatik der Bantusprachen. Zweite auflage. Hamburg : Eckardt \& Messtorf.

Posthumus, L.C. 1978. Die kopulatiewe van Zulu met verwysing na ander Bantoetale. Bloemfontein : Universiteit van die Oranje-Vrystaat. (M.A.-verhandeling.)

Posthumus, L.C. 1980. Relatives and adjectives as nouns in copulative wordgroups with special reference to Zulu. In: Wentzel, P.J. (ed.) Third Africa Languages Congress of Unisa. Pretoria : Unisa. p. 254-273.

Posthumus, L.C. 1988. Identifying copulatives in Zulu and Southern Sotho. South African Journal of African Languages, 8(2):61-64.

Posthumus, L.C. 1994. Word-based versus root-based morphology in the African languages. South African Journal of African Languages, 14(1):28-36.

Poulos, G. 1982. Issues in Zulu relativization. Grahamstown : Rhodes University. (Ph.D.-thesis.)

Poulos, G. 1990. A linguistic analysis of Venda. Pretoria : Via Afrika.

Van Eeden, B.I.C. 1956. Zoeloe-grammatika. Stellenbosch : Universiteit Uitgewers.

Van Wyk, E.B. 1953. Die kopulatiewe van Noord-Sotho. Pretoria : Universiteit van Pretoria. (M.A.-verhandeling.)

Van Wyk, E.B. 1958. Woordverdeling in Noord-Sotho en Zoeloe - 'n Bydrae tot die vraagstuk van woordidentifikasie in die Bantoetale. Pretoria : Universiteit van Pretoria. (Proefskrif.)

Van Wyk, E.B. 1967. Northern Sotho. Lingua, 17:230-261.

Van Wyk, E.B. 1968. Die invloed van die Europese tale en die Europese linguistiese tradisie op die studie van die Bantoetale. In: Cronje, G. (red.) Kultuurbeïnvloeding tussen Blankes en Bantoe in S.A. Pretoria : Van Schaik. p. 85105.

Wilkes, A. 1974. Oor die sogenaamde eksklusiewe kwantitatiewe van Zulu. Studies in Bantoetale, 1.1-1.2:76-86.

Wilkes, A. 1976. Oor die voornaamwoode van Zulu met besondere verwysing na die sogenaamde demonstratiewe en absolute voornaamwoorde. Studies in Bantoetale, 3(1):60-83.

Wilkes, A. 1987. Comments on the function of the abbreviated absolute pronouns in Zulu grammar. South African Journal of African Languages, 7(4):137-142. 
Ziervogel, D., Louw, J.A. \& Taljaard, P.C. 1978. A handbook of the Zulu language. First edition. Pretoria : Van Schaik.

\section{Kernwoorde:}

partikelwoorde

Van Wyk se woordteorie toegepas op Zoeloe woordidentifikasie in Zoeloe woordklasse in Zoeloe woordklassifikasie in Zoeloe

\section{Key concepts:}

particle words

Van Wyk's word theory applied to Zulu

word classes in Zulu

word classification in Zulu

word identification in Zulu 